\title{
A better place
}

\section{Craig Berry and Arianna Giovannini}

The increased interest in 'the North' in the UK in the post-crisis period among scholars, policy-makers and, to some extent, the general public should not surprise us. The apparent over-reliance of the UK economy (and Exchequer revenues) on industries concentrated in London and the South East was regularly noted by policy elites, even before 2008. After the crisis, this notion became one of the major tropes of elite-level political discourses on the UK's economic predicament (Berry and Hay, 2016). However, the (re)emergence of the North as national-level political issue is reflective also of a more profound shift. Crises destroy complacency about the basic foundations of social organisation, of which physical space is probably the most fundamental. Place, and associated concerns around identity and belonging, has therefore become a key dimension of numerous political and policy dilemmas in the UK (Berry, 2016b). The North is not the only dimension upon which this emerging politics of place is evident; the crisis appears to have unleashed or unearthed a wider set of anxieties about the security of forms of spatial organisation - our home, our neighbourhood, our city, our country - which were once taken for granted, or more precisely, we once assumed were immune to the ebbs and flows of the wider economy.

The recent rise of English national identity, and its politicisation, is perhaps the most important example of this anxiety for our purposes (see Kenny, 2014; Kenny, 2015; Wyn Jones et al, 2012). The debate over the role and place of Scotland within the UK, thrown into sharp relief by the 2014 independence referendum and more recent arguments about a potential 'IndyRef 2', has also played an important role in accentuating the political relevance of place. On the one hand, 'the Scottish question' has helped to reinforce emerging grievances within England, promoting a reactionary type of nationalism which depicts the English people as being denied the rights enjoyed by other nations. We can speculate that this version of English anxiety was reflected, at least in part, by the UK's vote to leave the European Union. On the other hand, and perhaps more importantly, the Scottish case has also prompted discussions revolving around a more progressive sense of place, especially in areas, such as the North of England, with distinctive regional identities (Willet and Giovannini, 2014). Indeed, there is evidence of an emerging 'place-based self-discovery' from the bottom-up in the North, reflected in the rise of civil society and political groups which uphold the civic and territorial distinctiveness of the North or its constituent parts (Giovannini, 2016). While such groups in the North invariably tend towards the proremain position of their equivalents in Scotland, their political claims are clearly buttressed by an apparent desire to, in the words of the pro-Brexit campaign, 'take back control' among many local communities in England, not least the North.

Of course, the political achievements of these groups in the North have, to date, been extremely limited. It appears at present that the right is the main beneficiary of England's place-based political anxieties: the Conservative Party's promotion of the Northern Powerhouse (and the devolution and local growth agendas more generally) since 2010 represents, unquestionably, an attempt to capitalise upon concerns about place in order to refresh its base of supporters in a post-crisis environment in which 
previous political certainties have been undermined. To date, the traditional, nationally-constituted centre-left has not produced a compelling alternative (Berry, 2016a). Attempts by various centre-left figures to commandeer the mantra of 'take back control' for their rather conventional liberal or social democratic political aims, albeit with support for devolution now more firmly central within their programmes, have yet to coalesce into a realisable political strategy.

It is vital that scholarly attention is turned to the politics of place. But this alone would be insufficient to understand the pursuit of economic development in the North; we argue that a political economy of place is also required. What is happening in and to the North is part of much broader processes of capitalist restructuring, evident long before 2008, in which places are becoming more different and, at the same time, more connected. New, transnational patterns of inequality are one of the main characteristics of these processes, both transforming and reinforcing pre-existing geographical schisms in countries like the UK (McCann, 2016; Peck and Theodore, 2007). In short, anxieties around place are intimately connected to questions around production and distribution. An understanding of both sets of issues is required if we are to explain not simply why policy elites are interested in the North, but why this interest has taken the form that is has, and the implications that related policy initiatives will have on the long-term development of the North and its constituent parts. This book offers only an initial foray into this intellectual agenda, drawing upon work undertaken by academic experts across a range of relevant disciplines. We are convinced, however, that both the rationale and the raw ingredients for a criticallyoriented 'local political economy' approach exists, combining economic geography's focus on the spatiality of economic organisation, connections between sites of production and the unevenness of socio-economic life, and political economy's abiding interest in the role of power, institutions and ideas - at the national and international levels - in determining how capitalist economies develop (Cox, 1987; Jones, 2015; MacKinnon et al, 2015; Martin, 2015; Watson, 2005).

While acknowledging the varied empirical focus and disciplinary background of the authors, we believe eight key lessons can be distilled from the book's analyses. First, the multiple developmental dilemmas facing the North are very longstanding in nature. The 2008 economic crisis may have transformed the rubric through which these dilemmas are confronted, but has probably sharpened their bite as well as providing an opportunity to illuminate their obstinacy. Second, many chapters have stressed that the notion of the North-South divide dominates the debate on economic development in the North, and the governance of development, in ways that are no longer particularly productive. It is apparent that the North continues to be framed mainly in negative terms, insofar as it needs to 'catch up' to the South. However, the presence of spatial economic imbalance in the UK is not merely related to the idea of a 'problematic North'; instead it is underpinned by a systemic London-centric bias, and should be understood as an entrenched, persistent and institutionalised feature of the national political economy. As such, the role of the South - and in particular the concentration of economic, financial and political power in London - in relation to the North needs to be problematised. Even if (parts of) the South could be said to represent an exemplar for the North to learn from, we would be required to acknowledge the role that the North's subservience plays in the South's developmental success. 
Third, several accounts in the book have shed light on the limits of urban agglomeration in theory and practice. This epistemological framing currently provides a large part of the rationale for the Northern Powerhouse and related agendas, and has been absorbed into elite practices in the North, as well as national policy for the North. Agglomeration-based theory overlooks too much of what in practice is 'holding back' the North, and the apparent enablement of agglomerative dynamics through public policy is likely to widen, rather than bridge, existing gaps not only between the North and the South, but also across the North. Fourth, the importance of appraising the politics of economic development in the North via an understanding of where Northern cities and regions are situated within wider domestic and international production processes, and, importantly, how the North's status within these processes is upheld by the maintenance of a national growth model. Whilst the Northern Powerhouse (and, as discussed below, the devolution deals linked to it) touches upon post-crisis concerns around place and empowerment, beyond the rhetoric Northern regions continue to have limited powers over the structures and practices that govern their economic make-up.

Fifth, one of the themes running throughout the book is the dysfunctional nature of the governance of economic development in the North. The introduction of new (and often overlapping) institutional structures from the top down, adding complexity to an already over-crowded system of governance, is a core trait of the governance system in this regard. Crucially, these new institutional arrangements graft onto a policy framework that is led by central government and lacks coherence, especially in terms of strategic co-ordination, long-term planning and funding - hindering the development of place-specific architectures and sub-national policy. Sixth, and related to this, the disorderly nature of this framework is epitomised by the uneven governance of devolution deals. While presented as key to unlocking economic development in the North, in practice 'devo-deals' are emerging as mere bespoke partnership agreements between national and local elites, which involve modest powers as well as vast liabilities, are based on artificial (and often problematic) functional geographies, and have little resonance among local communities. As emphasised by several contributions in this volume, devolution could benefit and empower those areas, such as Greater Manchester, that already have a degree of institutional maturity and experience of co-operation between local authorities. However, by the same token, other parts of the North where such frameworks are nascent or still missing could end up (and in many respects already are) being marginalised, fostering dynamics of local tribalism, competition and suspicion between localities - within which local interests supersede cross-regional and/or panNorthern ones.

This points us towards the seventh main lesson that can be taken from the book, that is, the lack of democratic accountability evident in the devolution agenda and local governance processes in the North more generally. The top-down approach to state restructuring and institutional (re)arrangement promoted by central government has facilitated practices of inclusion and exclusion in the negotiation and decisionmaking processes that underpin 'devo deals'. Generally speaking, only certain actors (typically political leaders and business representatives in the so-called 'core-cities') have been granted a voice, and residents are seldom aware of, let alone involved in, the apparent transformation of the means by which their local economies are ostensibly being shaped. That the Northern Powerhouse and related initiatives have been justified precisely on the basis that they enhance local democracy serves to compound a longstanding 'democratic deficit' within the North. Finally, there are a 
set of specific lessons - explored most extensively in the chapters by Bailey, and Muldoon-Smith and Greenhalgh - around tax reform and fiscal decentralisation. Moves towards making local authorities more dependent on the taxes they raise locally reinforces the structural disadvantage of the North. There are fewer profitable firms and wealthy individuals in Northern cities and regions from which tax revenue can be raised and, moreover, strong incentives for areas in the North to cut local taxes in the hope of attracting such firms and individuals into their jurisdiction (invariably creating mutually destructively competitive relations between different parts of the North). At the same time, local authorities are increasingly expected to shoulder the burden for financing public services in the context of austerity. More generally, the differential impact of austerity on the North features in several of the book's chapters.

$*$

Politics is about power and, in simple terms, political economy is concerned with the role of political power in shaping economic life. While recognising that power takes many forms, and that the process for devolving some formal, institutional powers to some Northern city-regions is hugely flawed, our view - generally supported by the analyses of this book - is that the opportunity represented by the devolution agenda as it stands must be seized by the North. The devolution on offer is limited and conditional, and in some ways reinforces the North's subservience within the national development model, but also arises in part from evident weaknesses in the UK's overcentralised political economy. There is a chance therefore that the North can push now for a more progressive, ambitious and genuinely empowering model of devolution, and one which assists efforts to construct a new role for Northern cities and regions in a transformed UK growth model. We should of course be under no illusion that more power to the North would allow it to buck the transnational core/periphery dynamics which shape its political-economic environments. Ultimately, however, more power is better than less power - especially given the disappointing track record of national political authorities in the UK in terms of supporting Northern regions in responding to wider shifts in capitalist organisation.

Although it would be impossible to delineate a comprehensive agenda here, we believe several other, related policy reforms should be pursued in order to enable the North to develop its economy in a more sustainable manner. The devolution agenda must be based on a profound rethinking of centre-local relations; we should focus not only on rearranging local government, but also a radical transformation of governance structures at all levels, established in a new constitutional settlement. The centre itself would be reformed in this process, via reconsideration of the function of key macroeconomic policy bodies such as the Treasury and the Bank of England, the relocation of some of the core functions of government departments - and perhaps even Parliament - away from the capital. Reform of the upper chamber, the House of Lords, should include elements of regional representation. Moreover, the

institutional reforms that do take place within local government in the North should not be constrained by prescriptive forms of governance imposed by the centre, which are increasingly based exclusively on the spatial imaginary of the city-region. We believe that the most suitable solution for the North would be to allow for the creation of multiple layers of political authority, that is, at metropolitan, regional, and panNorthern levels.

Crucially, sub-national governance in the North should be democratised as well as federalised. In a political climate characterised by increasing levels of 
disillusionment, devolution could and should provide an effective way to improve the relationship between citizens and the political system. To achieve this, local communities must be given a say over decisions concerning how the North should be governed, and should be actively engaged in the debate about their political and economic future. Too often, local political leaders in the North themselves seek to side-line the inputs of the communities they represent. They should instead seize the opportunity to provide a collective voice for their localities, their regions and the North in general - a platform which would in turn enhance their legitimacy in negotiations with the centre over power and resources.

Economic development in the North will be impossible without a UK-wide industrial strategy that builds upon the economic strengths and potential of Northern cities and regions. Industrial strategy means that government thinks strategically about how to utilise its resources and the inherent strengths of the sovereign state (such as its longer time-horizons and unparalleled ability to spread risk) to improve the productive capacity of the economy. The UK has remarkably few robust organs of industrial strategy at either national or local levels - and those that have existed at the sub-national level have been effectively neutered or abolished in recent years, despite the rhetorical focus on 'rebalancing' among policy elites. At the same time, it is clear that the UK state has pursued an industrial strategy by other means in recent decades, to the benefit of the finance sector and the City of London. That this strategy has proven unsustainable in developmental terms (from a national perspective) underlines the need for an industrial strategy that is place-based rather than place-blind, recognising the particular assets of different areas rather than assuming each can or should seek to replicate the local developmental model of London. Northern cities and regions must be mobilised in service of a new, nationwide industrial strategy and, at the same time, empowered to determine the specific mix of industrial policy measures appropriate to their local economies.

The inherent bias of financial institutions to London-based economic activity - an inevitable consequence of a London-centric growth model - means that reforms to the regulation of the banking sector and capital markets must be central to any industrial policy agenda. This would better enable much-needed infrastructure investment in the North, which is presently disincentivised within finance sector business models, but more generally provide greater opportunities for long-term capital investment by private companies. At a seemingly more mundane level, local authorities must be able to devote greater resources to understanding the local economies over which they preside. The provision of detailed information on the composition and performance of local economies in England is inadequate and, coupled with a lack of economic and industrial policy expertise among local officials, serves to undermine the North's ability to demonstrate its particular needs, and indeed its value to the national economy. Furthermore, it is vital that the interests of the North are central to the Brexit process. At the very least, European funds invested into the North must be replaced, and enhanced, by the UK government in due course. More fundamentally, given the significance to European production networks to productive activity in the North, Northern cities and regions must be treated by central government as a partner when negotiating a new trading relationship with the continuing EU.

The question of fiscal decentralisation hangs over any attempt to devolve meaningful economic powers to the local level. It is clear that the reform of local taxes associated with the Northern Powerhouse and devolution agendas poses a serious challenge to economic development in the North. New freedoms to raise local business and property taxes is connected to efforts to paper over the cracks in public 
services created by austerity, and new freedoms to lower local taxes constitutes an attempt by central government to instil a 'race to the bottom' among local authorities in order to attract exogenous investment in high-employment (but low-wage) sectors. The developmental model implied by this scenario is not one that is likely to benefit the North. It is not appropriate for any locality, particularly structurally disadvantaged areas in the North, to become more dependent on the revenue it is able to raise only within its own boundaries to fund local government. Instead, comprehensive tax reform should be subject to a new centre-local settlement, enabling more opportunities, not fewer, for the redistribution of tax revenues between areas - as well as providing for a more nimble tax system that can prevent over-heating in certain local economies where necessary, and better ensures the success of prosperous areas is not threatened by a lack of economic resilience elsewhere in the domestic economy that they are inherently dependent upon (Engelen et al, 2016). This does not mean that local authorities should not have some tax powers; they should, for instance, have the ability to adjust national tax policies locally in order combat rent-seeking behaviour connected to land and property holdings, as and when such behaviour stands in the way of local economic development.

There is also an array of more limited and straightforward reforms that could make a significant difference to local economic development in the North (see McInroy et al, 2016). For example, national purchasing frameworks and restrictive procurement practices prevent local economies from utilising the potential of 'anchor institutions' within their economy. Anchors are organisations which have a sizeable local presence, usually through a combination of being large-scale employers, one of the largest purchasers of goods and services in the locality, controlling large areas of land, and/or having relatively fixed assets. Arguably, the North's economy is stronger than it appears, given the location of anchors within 'foundational' economic sectors such as health and education, yet it is not sufficiently able to build upon this strength in the construction of a development model more tailored to the characteristics of constituent cities and regions. Local authorities should be empowered to use their own purchasing power - and direct that of locally rooted employers - to, for instance, encourage suppliers to create quality career progression opportunities for their workforces, provide support to the voluntary and community sector, and indeed invest in local supply chain development. The notion of anchor institutions is usually applied to public sector or pseudo-public sector organisations, but its logic could be extended to the private sector, whereby large private firms were supported to operate in the local economy on the basis of a social license which would ensure their profitmaking activities are aligned with local developmental needs (Bowman et al, 2014).

Above all, and encompassing all the points raised thus far, the dominant narrative that portrays the North as inherently problematic should be reversed. In many respects, such top-down, London-centric framing of the North has been internalised by national and local elites, and is reflected in the current devolution and Northern Powerhouse agenda. Yet while the North has distinctive characteristics, it is not uniquely disadvantaged, and the path towards de-development is not set in stone. A national conversation that focuses on the 'divide' between the North and South while rightly illuminating endemic inequalities - leads to the political-economic interactions between different parts of the UK being overlooked and under-theorised. Similarly, a seemingly progressive agenda focused on helping the North to 'catch up' to more developed local economies is a narrative which paints the North as failing, rather than constrained. We need to turn the current motifs of 'empowerment' and 'localism' from rhetoric into reality. To achieve this, local leaders need to be bolder, 
and to coalesce, overcoming local tribalism, and focusing on building cohesive political agenda across the Northern regions. They should also mobilise and find strength in the local and regional identities that characterise the North - so as to build an inclusive political project based on shared civic and community values that speaks both for and to the people, and aims at actively involving them in the construction of a more progressive and sustainable developmental path.

\section{References}

Berry, Craig (2016a). Austerity Politics and UK Economic Policy, Basingstoke: Palgrave.

Berry, Craig (2016b). 'The resurrected right and disoriented left: growth model failure and the nascent politics of a transformative narrative', SPERI Paper No.27. Available from: http://speri.dept.shef.ac.uk/wp-content/uploads/2016/02/SPERIPaper-27-The-Resurrected-Right-and-Disoriented-Left.pdf [accessed 1 March 2017].

Berry, Craig and Hay, Colin (2016). 'The Great British 'rebalancing' act: the construction and implementation of an economic imperative for exceptional times', British Journal of Politics and International Relations, 18(1), 3-25.

Bowman, Andrew, Ertürk, Ismail, Froud, Julie, Johal, Sukhdev, Law, John, Leaver, Adam, Moran, Michael, Williams, Karel (2014). The End of the Experiment. From Competition to the Foundational Economy. Manchester: Manchester University Press.

Cox, Robert W. (1987). Production, Power and World Order: Social Forces in the Making of History, New York: Columbia University Press.

Engelen, Ewald, Froud, Julie, Johal, Sukhdev, Salento, Angelo, Williams, Karel (2016). 'How cities work: a policy agenda for the grounded city', CRESC Working Paper No.141. Available from: http://www.cresc.ac.uk/medialibrary/workingpapers/wp141.pdf [accessed 1 March 2017].

Giovannini, Arianna (2016). "Towards a "New English Regionalism" in the North? The Case of Yorkshire First', The Political Quarterly, 87(4), 590-600.

Jones, Calvin (2015). 'On capital, space and the world system: a response to Ron Martin', Territory, Politics, Governance. 3(3), 273-293.

Kenny, Michael (2014). The Politics of English Nationhood. Oxford: Oxford University Press.

Kenny, Michael (2015). 'The origins and drivers of English nationhood', British Politics, 10(3), 356-61.

Martin, Ron (2015). 'Rebalancing the spatial economy: the challenge for regional theory', in Territory, Politics, Governance. 3(3), 236-272.

MacKinnon, Danny, Cumbers, Andrew, Pike, Andy, Birch, Kean and McMaster, Robert (2015). 'Evolution in economic geography: institutions, political economy, and adaptation', in Economic Geography. 85(2), 129-150.

McCann, Philip (2016). The UK Regional-National Economic Problem: Geography, Globalisation and Governance, London: Routledge.

McInroy, Neil, Berry, Craig, Hunt, Tom, Whillans-Welldrake, Amy-Grace and Todd, Matthew (2016). The Real Deal: Pushing the Parameters of Devolution Deals, SPERI/CLES. Available from: http://speri.dept.shef.ac.uk/wpcontent/uploads/2016/07/The-Real-Deal-SPERI-CLES.pdf [accessed 1 March 2017]. 
Moulaert, Frank, Jessop, Bob \& Mehmood, Abid (2016). 'Agency, structure, institutions, discourse (ASID) in urban and regional development', in International Journal of Urban Sciences, 20(2), 167-187.

Peck, Jamie and Theodore, Nik (2007) 'Variegated capitalism', Human Geography, 31(6), 731-772.

Watson, Matthew (2005). Foundations of International Political Economy, Basingstoke: Palgrave.

Willett, Joanie and Giovannini, Arianna (2014). 'The uneven path of UK devolution: top-down vs. bottom-up regionalism in England-Cornwall and the North-East compared', Political Studies, 62(2), 343-60.

Wyn Jones, Richard, Lodge, Guy, Henderson, Ailsa and Wincott, Daniel (2012). The Dog That Finally Barked: England as an Emerging Political Community, London: IPPR.

Available

from: http://www.ippr.org/files/images/media/files/publication/2012/02/dog-that-finallybarked_englishness_Jan2012_8542.pdf?noredirect=1 [accessed 1 March 2017]. 